\title{
The U.S. Fish Commission Steamer Albatross in the Strait of Georgia and Queen Charlotte Strait, British Columbia, Canada in June 1903
}

\author{
COLIN LEVINGS
}

\section{Introduction}

The U.S. Commission of Fish and Fisheries (U.S. Fish Commission) Steamer Albatross (hereafter Albatross) is renowned in the history of oceanography and conducted extensive research in many parts of the world. Several key papers summarize the activities of the Albatross and her voyages around the U.S. and Canadian coasts, South America, the Philippines, Japan, and elsewhere (Hedgpeth and Schmitt, 1945; Roppell, 2004). However, information on most of her voyages in British Columbia (B.C.), Canada, is scattered through the literature, with specific details dispersed in published scientific logs, navigation bridge logs, and annual reports of the U.S. Fish Commission or its successor, the U.S. Bureau of Fisheries. Exceptions are the paper by Wilby (1934) and mentions in the recent book by $\mathrm{Pi}$ etsch and Orr (2019) on ichthyological findings from the ship in B.C. waters and the Salish Sea, respectively.

The Albatross routinely travelled through B.C. waters en route to Alas-

Colin Levings is a retired Research Scientist with Fisheries and Oceans Canada, Lions Bay, B.C. V0N 2E0, and Adjunct Faculty, Institute of Resources, Environment and Sustainability, University of British Columbia, Vancouver, B.C. V6T 1 Z4.

doi: https://doi.org/10.7755/MFR.83.1-2.2 ka for fisheries patrols in Alaska or oceanographic research (Johnstone, 1977). Between 1888 and 1914 the ship had at least 12 transits of the B.C. inner coast. ${ }^{1}$ Her routing was often through the Canadian Inside Passage, from bases in Washington or California, and two of her regular ports of call were Departure Bay, near Nanaimo, and Union Bay, near Comox, for coal.

In this paper I focus on a subsample of the Albatross's work in British Columbia, specifically a 1903 voyage (Fig. 1) through the Canadian Inside Passage to Alaska which began in Seattle, Wash., on 18 June. This was the first part of a transit to Alaska on a special mission ordered by U.S. President Theodore Roosevelt in 1902 to investigate Pacific salmon (Oncorhynchus spp.) fisheries in the Territory. For context, this fisheries mission was focused on investigations in areas of southeast Alaska, at the time though the ownership was being disputed between the United States, Great Britain, Canada, and British Columbia. The boundary was established by an International Tribunal in October 1903 (McDorman, (2009) provides details). Furthermore, the U.S. Fish Commission was representative of activities

${ }^{1} \log$ books of the U.S. Fish Commission, 19th and 20th centuries. https://www.navalhistory.net/OW-US/Albatross/USFCS_Albatross-1900-1901.htm (accessed 18 September 2020). during the Progressive Era in the United States, when it was thought that science should be brought to bear on political, social, and economic problems, including the destruction of natural resources such as fisheries (Hay, 1959, cited in Jennings, 2014).

The 1903 Albatross expedition and the special mission was deemed to be the most important assignment ever given initiative to the U.S. Fish Commission at that time (Evening Star, 1903) and was staffed by some of the key U.S. fisheries scientists of the time such as David Starr Jordan (Shor, 2020), Barton Warren Evermann (Jennings, 1997), and Charles Henry Gilbert (Dunn, 1997). Cloudsley Louis Rutter, another prominent fisheries scientist who had worked as the Resident Naturalist on the ship, did not sail on the Albatross on this particular trip but served the special mission with his investigations on Kodiak Island (Jennings, 2014).

After outlining the sources of data for my description of the Strait of Georgia and Queen Charlotte Strait components of the voyage, I describe the results of the biological and oceanographic investigations and comment on how such cross-border investigations facilitated work by Canadian biologists. A concluding section deals with the legacy of the Albatross in B.C. waters.
ABSTRACT-The iconic research vessel U.S. Fish Commission Steamer Albatross was a frequent visitor to the west coast of Canada as she transited the Canadian Inside Passage to patrol and oceanographic duties in Alaska. Her June 1903 sampling in the Strait of Georgia and Queen Charlotte
Strait while en route for Pacific salmon (Oncorhynchus spp.) studies in Alaska yielded important early data on oceanographic conditions and records of fish and invertebrates. The cruise yielded some of the earliest bottom temperature data for the region, 44 fish species were obtained by beam trawl, beach seine, gill net, and hook and line, and a variety of invertebrate collections were made. Albatross investigations on this voyage, and others, left a legacy that established British Columbia marine biodiversity baselines and facilitated collaborations between Canadian and American biologists. 


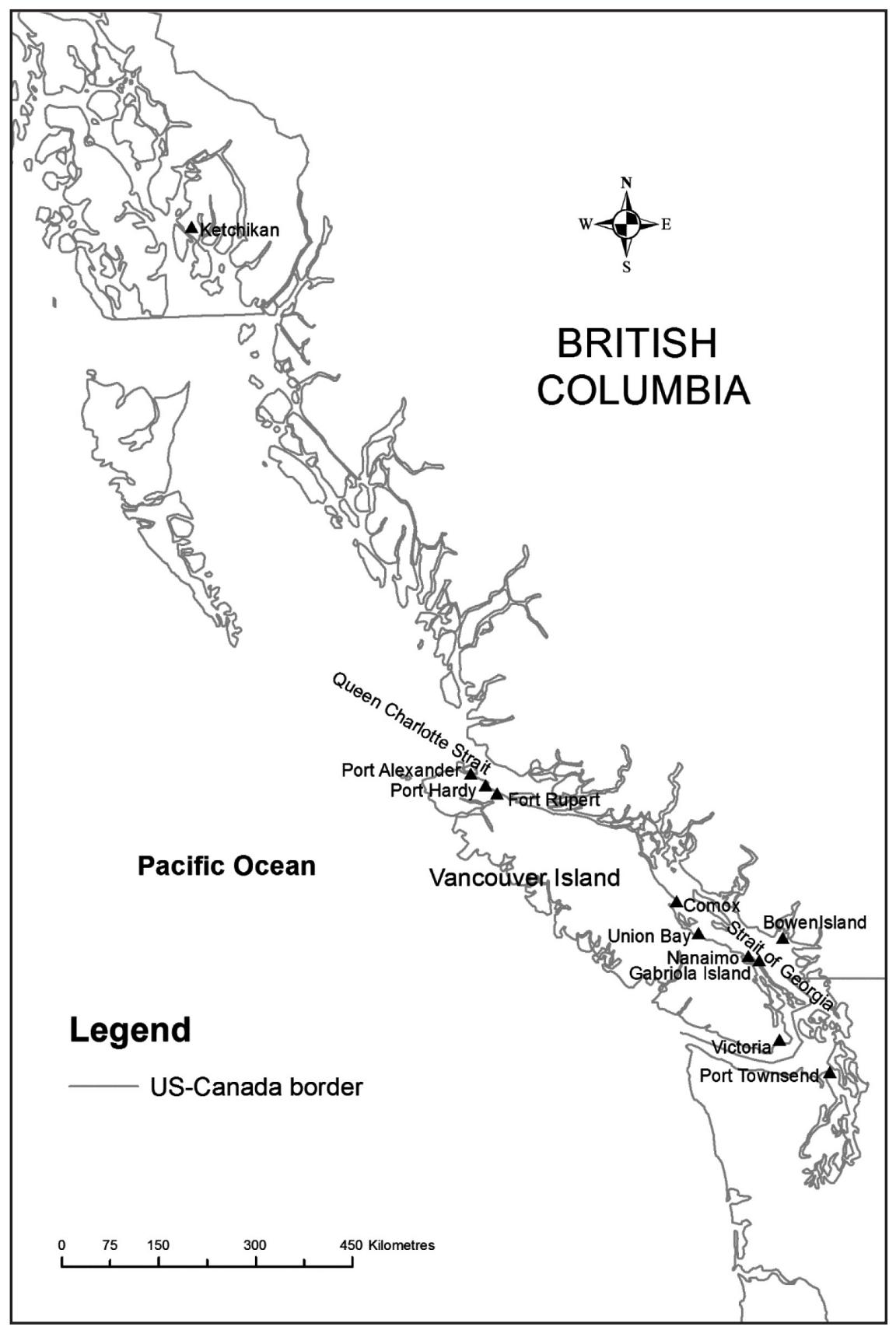

Figure 1.-The coast of British Columbia showing sampling locations for the Albatross in June 1903.

The June 1903 Albatross Voyage Results

The Alaska Salmon Commission was headed by David Starr Jordan and Barton Warren Evermann and much of its work was conducted using the Alba- tross for the fisheries investigations in Alaska as described above. Although not specifically described in her orders from the President, the Albatross also conducted extensive oceanographic and biological sampling in B.C. waters on the trip.
While the preliminary report of the Commission is well described and available (Jordan and Evermann, 1904), the details of the B.C. part of the voyage to Alaska were difficult to track down. As did Hedgpeth and Schmitt (1945), I found her navigation bridge logs for June 1903 are not available. Fassett (1905) provided a description of the beam trawl and hydrographic work on the voyage, and the well-organized system of consecutively numbered station codes for the ship was extremely valuable in tracking the biological samples from trawl hauls. The detailed logs of the trawl and hydrographic work which support Fasset's (1905) data are also available in the Smithsonian Institution archives. However, Fassett (1905) only reported hydrographic (temperature, depth) and sediment data; few biological results are given, other than notes on size of the catch in the beam trawls.

While reviewing Fassett's data I noticed some anomalies in the timeline of the work. The ship arrived in Nanaimo on 19 June and worked in southern B.C. waters in the Strait of Georgia on 19 and 20 June. Then there was a gap of 5 days. After sampling in Queen Charlotte Strait on 25 June (near the north end of Vancouver Island) there was another 6 days at sea unaccounted for as the next set of data in Fassett's report was on 1 July in Puget Sound, Wash., rather than further north in British Columbia or in Alaska, as might be expected. The ship worked in Puget Sound for a few days and then headed up the Canadian Inside Passage again to Alaska without further B.C. sampling.

I resolved the missing information and completed her itinerary by studying the personal notes of Evermann, which I found archived in the California Academy of Sciences (Evermann, 1903). These notes considerably expanded our knowledge of the biological sampling from the voyage, especially shoreline work, which was not reported by Fassett (1905). As well, a newspaper article published in a Victoria newspaper (The Daily Colonist, 1903) reporting an interview with Jor- 
dan in Nanaimo and an article in the Washington (D.C.) Times (Washington (D.C.) Times, 1903) helped explain why the expedition was particularly interested in sampling in the Strait of Georgia.

\section{Nanaimo and Bowen Island, 19 and 20 June (Strait of Georgia)}

Under the command of Lt. Franklin Swift, U.S.N., the Albatross left Seattle on the evening of 18 June en route to Alaska via the Canadian Inside Passage. The Albatross's first port of call in Canada was at Nanaimo, B.C., on 19 June.

Jordan and Evermann arrived by train at 1:00 p.m. on 19 June from Victoria and joined the rest of the scientific staff who were already on the ship. The scientific staff included Jordan, Evermann, U.S. Fish Commissioners staff Alvin Burton Alexander, J. N. Wesner, and Harold C. Fassett; Harold Heath from Stanford University, an expert on molluses; Harold Jordan, son of D. S. Jordan; and assistants.

According to the Victoria Times Colonist article Jordan was specifically interested in obtaining specimens of an unusual fish (described in the Washington Times article as a "peculiar kind of red fish") which had been reported from Nanaimo area waters by a local resident and forwarded to B.C. Provincial Museum (BCPM) naturalist John Fannin, who in turn had contacted Jordan. Jordan described the fish as Zapora silenus (Jordan, 1896), and it appears that considerable effort may have been directed toward obtaining more specimens.

On the afternoon of 19 June, the $\mathrm{Al}$ batross made two bottom trawls (54$97 \mathrm{~m}$ ) and one surface trawl off Sharp Point near Nanaimo. On 20 June five trawls (32-320 m) were completed on Halibut Bank (off Cape Roger Curtis, Bowen Island) as well two surface trawls and two handline sets (20-42 $\mathrm{m})$. One trawl (287-420 m) was made off Entrance Island, also near Nanaimo (Fassett, 1905). Some biological results from these stations can be gleaned from the 16 fish species records mentioned in Wilby (1934) and
Evermann and Goldsborough (1907) using the station codes as a tracking system.

Jordan was unsuccessful in his hunt for Zapora silenus (now known as the prowfish) (The Daily Colonist, 1903) which is now known to be extremely rare in the Strait of Georgia (Pietsch and Orr, 2019). As well, this species is not listed in the records of the trip by Evermann and Goldsborough (1907). Other fish sampling was more opportunistic. On the evening of 19 June, Alexander set a gillnet (13 cm mesh) at the south side of the outer harbor. Pacific spiny dogfish, Squalus suckleyi, and spotted ratfish, Hydrolagus colliei, were found in the gillnet the following morning and coho salmon, O. kisutch, were also caught by trolling in the same area (Evermann and Goldsborough, 1907).

Additional biological data from the trawl hauls, for example new or rare species of invertebrates found in the mud or sand from the trawls, are scattered throughout the taxonomic literature, but some are summarized in reports from the expedition, sometimes known as the Albatross Alaska Salmon Commission (or Investigation) reports. As an example, Richardson (1905) of the U.S. National Museum described a species from a Halibut Bank station in her compilation of isopods from the expedition. There are numerous records in the Smithsonian Institutions' National Museum of Natural History (NMNH) of other invertebrates from the trawling (listed under specific collecting locations (e.g., Bowen Island), usually accompanied by station number).

Data on bottom sediment type and temperatures were also collected at the trawl stations. (Fassett, 1905). Sediment types at each of the three areas sampled ranged from sand to mud to rocky. Bottom temperatures were measured with state of the art Negretti and Zambra reversing thermometers. Bottom temperatures at Sharp Point ranged from $8.4^{\circ} \mathrm{C}$ to $8.6^{\circ} \mathrm{C}$, at Halibut Bank from $8.2^{\circ} \mathrm{C}$ to $12.1^{\circ} \mathrm{C}$, and at Entrance Island from $8.2^{\circ} \mathrm{C}$ to $8.7^{\circ} \mathrm{C}$. Surface and air temperatures were also obtained.
On 20 June Evermann went with two small boats and six men to nearby Gabriola Island where they collected shore samples of invertebrates at sites they called Taylor Bay and Lora Bay. They met "a Rev Taylor," and Evermann noted he was "somewhat of a naturalist" and in his cabin they saw "several boxes of fossils, insects." In 1908 Reverend George W. Taylor became the first Curator of Canada's first marine station on the west coast (the Pacific Biological Station on Departure Bay, Nanaimo) and was very influential in this role and prior to that, as I describe in a later section.

This record of Taylor's work may be one of his first introductions to the Albatross and her biologists. Some of the material collected on Gabriola Island by Evermann was deposited in the NMNH, for example the shore crab, Hemigrapsus nudus (Rathbun, 1918). However, there are some anomalies in the collection dates for Rathbun (1918:291) notes Albatross collection dates for this species on 19 and 20 June on Gabriola Island. Evermann also apparently beach seined or shore collected fish at Gabriola Island on 20 June as eight species are reported from here in Evermann and Goldsborough (1907).

\section{Union Bay-Comox, 21-24 June (Strait of Georgia)}

The Albatross arrived at Union Bay, on Baynes Sound, at about 1 p.m. on 21 June after leaving Nanaimo that morning. The purpose of this stop was to load coal, and the vessel had made this port on many of her cruises up or down the Canadian Inside Passage. During their stay, Evermann and Alexander collected some land invertebrates and also went fishing on a lake Evermann called San Mateo Lake (likely the body of water now known as Langley Lake) where he caught a cutthroat trout, Salmo clarki (now Oncorhynchus clarkii) on 22 June (also mentioned in detail in Evermann and Goldsborough, 1907).

Although not mentioned in Evermann (1903), there is a record of steelhead trout, Salmo gairdneri from 
Courtney Lake (near Union Bay, possibly Comox Lake near the close by town of Courtenay, as there has never been a lake called Courtenay Lake in the vicinity) on 22 June 1903 in Evermann and Goldsborough (1907), probably caught by another member of the expedition or perhaps a crew member. This specimen, as discussed by Evermann and Goldsborough (1907) in their general narrative about steelhead, was possibly a rainbow trout (now known as Oncorynchus mykiss). On 23 June Evermann (1903) reported doing a beach seine at low tide and caught "a few fish"- twelve species (includes lake-caught species) are reported in Evermann and Goldsborough (1907). There is also a record in the NMNH of a sea louse, Argulus pugettensis Dana, 1852, obtained from a coho salmon at Union Bay on 22 June.

Although not mentioned by Evermann, shore collections of invertebrates were made at Union Bay, notably polychaetes, which are mentioned in Moore (1908). There may have also been some shore collecting for invertebrates on nearby Denman Island as Rathbun (1918) mentions an Albatross collection of Hemigrapsus nudus from the island in June 1903-date and collector unspecified. In addition, the NMNH has a record of a collection of a hermit crab, Pagurus hirsutiusculus (Dana, 1851), collected on 22 June 1903 at Union Bay by the Albatross.

The ship left Union Bay at 10:15 a.m. on 24 June.

\section{Fort Rupert,} 25-26 June (Queen Charlotte Strait)

Early on the morning of 25 June the Albatross anchored in Beaver Bay, off Fort Rupert, B.C., and the adjacent Kwakiutl village of Tsaxis, about $5 \mathrm{~km}$ southeast of present-day Port Hardy. It is not clear why the expedition stopped at Fort Rupert, but the ship did sample there earlier in 1888. Beam trawl and hydrographic data from a station in mid-Queen Charlotte Strait in 435 $m$ water depth are given in Townsend (1901). The crew went ashore to harvest clams for the ship's stores (four barrels were gathered; Tanner, 1889), but there is no information on any shoreline biological sampling. There is a record of clam digging in Evermann's report so perhaps clamming was also the reason on the 1903 stop on 25 June.

Evermann, Alexander, and Harold Jordan went ashore at 7:15 a.m. for beach seining and shore collecting. The Albatross stood out to sea and spent the day doing beam trawls and hydrographic sampling mostly in the vicinity of Round Island, about $4 \mathrm{~km}$ offshore. Six beam trawls were completed with a depth range of $46 \mathrm{~m}$ to $145 \mathrm{~m}$. As well as sediment types, Fassett (1905) noted sponges at some stations. Six hydrographic stations were also conducted with bottom temperatures ranging from $7.5^{\circ} \mathrm{C}$ to $9.6^{\circ} \mathrm{C}$.

Evermann's notes from beach sampling showed that he sampled for fish in tide pools at low tide and did four beach seines at high tide. Salvelinus malma (Dolly Varden) and starry flounder, Platichthys stellatus, were most abundant in the beach seine, and staghorn sculpins, Leptocottus armatus, were commonly observed in the tide pools. These fish species are associated with brackish water so the fish sampling may have been conducted near an estuary. Invertebrates commonly observed included "giant clams, little neck clams and big crabs." Evermann and Goldsborough (1907) list more complete references to the Fort Rupert fish collections and include 21 species from trawling, beach seining, and hook and line fishing.

As with the sampling in the Strait of Georgia, samples of invertebrates from trawl hauls were sent to specialists for identification. For example, Bartsch (1917) described a new species of marine snail (Cerithiopsis (Cerithiopsis) charlottensis Bartsch, 1917) from a station (4204, not 4205 as Bartsch lists) off Round Island at Fort Rupert. Rathbun (1918) notes an Albatross collection of the shore crab Hemigrapsus oregonensis on 25 June at Fort Rupert and Moore (1908) described polychaetes.

Evermann returned to the ship at 5:30 p.m. to be greeted by bad news.
One of the Albatross crew was diagnosed with smallpox and the ship had to return to Port Townsend, Wash., to go into quarantine. The ship left Fort Rupert at 3:00 a.m. on 26 June arriving Port Townsend at 9 a.m. on 27 June. After working around the Port Townsend area for a few days, the Albatross left for Alaska again on 2 July. She anchored for the night on 3 July at Port Alexander, B.C., north of presentday Port Hardy but no sampling was conducted. Her next sampling episode was on 6 July at Boca de Quadra, near Ketchikan in southeast Alaska (Fassett, 1905).

\section{Legacy of the 1903 \\ Sampling in the Strait of Georgia and Queen Charlotte Strait}

The detailed biological and hydrographic sampling from the Albatross in June 1903 was an unusually focused and specialized activity for the ship while she was in Canadian Inside Passage waters. Presumably the organizers of the cruise put this ecological work on the itinerary as an extension of the Alaskan cruise as B.C. dredging is not mentioned in the ship's work plan for the trip as described by Roppel (2004).

The stop at Nanaimo and the sampling in the Strait of Georgia seems clearly to have been directed by Jordan toward prowfish - referring to the "peculiar red fish" the Washington Times (1903) article notes “...the sound (presumably the Strait of Georgia) is to be thoroughly dredged and the fish studied." The visit to Union Bay was for coaling but enabled beach sampling and the Fort Rupert visit may have been for clamming.

Unlike the trawling and hydrography, the shoreline surveys were rather general investigations. The 1888 sampling at Fort Rupert is the only other record of Albatross hydrographic work in Canadian Inside Passage waters other than the 1903 voyage (see U.S. Bureau of Fisheries, 1920) so the paper by Fassett (1905) reports some unique data, especially bottom temperature records, for the ship and region. The bottom temperature data from the Strait 
of Georgia are apparently not recorded in Canadian data files because existing DFO databases do not show any similar data before Tully's Strait of Georgia work in 1932 (Fisheries and Oceans Canada, 2020). Scagel and colleagues from the University of British Columbia provided temperature data from Queen Charlotte Strait in 1957, but the maximum depth sampled was only 15 m (Scagel, 1958).

The 1903 Albatross data are therefore probably the earliest bottom temperature records from the Strait of Georgia, as well as adding one more historical data point for Queen Charlotte Strait. While limited, and with the caveat that comparisons may be difficult because of possible technique differences, these do provide baseline information that might be relevant to present-day climate change and ocean temperature regime studies. The June 1903 cruise also provided baseline data on fish communities, at least at the presence or absence level (fish abundance/numbers do not seem to be recorded from the trawl surveys).

In all of the sampling, 44 fish species were collected. Although it appears that no new species of fish were found in the sampling, the beam trawl species records in Evermann and Goldsborough (1907) provide some of the first reports on fishes of the deeper water $(>100 \mathrm{~m})$ for the B.C. coast. Some were described as "ichthyological treasures" by noted Canadian fish biologist G. V Wilby a few decades later (Wilby, 1934). There were likely more new records for invertebrates than the few that I compiled in this paper, and a complete report would require more literature work.

The June 1903 shoreline sampling was more representative of the type of work conducted along the Canadian Inside Passage in previous and later Albatross cruises. The biologists aboard the Albatross likely sampled nearshore habitats on an opportunistic basis during her numerous Canadian Inside Passage trips, especially near Nanaimo (Departure Bay) and Comox (Union Bay) where the ship frequent- ly stopped for coaling on her way up or down the coast. It usually took two or three days for coaling so there was ample time for the naturalists to collect from nearby shores.

For example, during a coaling stop in 1890 at Nanaimo, Gilbert (1896) collected the sharpnose sculpin, Oligocottus acuticeps, in tide pools on Departure Bay. Alexander (1893) sampled with a drag (beach) seine near Comox and "caught no fish of economic importance" and Austin H. Clark (in Pawson and Pawson, 2018) remarked that during a stop at Union Bay for coal in 1906 "people have been collecting fishes and all sorts of other things along the shore". There are numerous mentions of Albatross collections of invertebrates from Comox and Union Bay in the NMNH, and thus there are likely many museum records of invertebrates taken along the coast in shoreline surveys in addition to the 1903 sampling on Gabriola Island, Union Bay, and at Fort Rupert.

In summary, the scientific legacy of the 1903 cruise of the USS Albatross in B.C. waters is unique relative to the other collections made from the ship along the Canadian Inside Passage, especially those made near Nanaimo and Comox, which were mainly opportunistic shoreline collections of fish and invertebrates. Over and above the bottom temperature data, the contribution to our knowledge of the biodiversity in these regions is very significant when one takes into account both shoreline and deeper bottom trawl collections. All fish and invertebrate collections were valuable for specialists working in U.S. museums and elsewhere in their descriptions of new species and their variability, thus contributing to the baseline knowledge of fish and invertebrate communities of the Strait of Georgia and Queen Charlotte Strait.

These studies may have been facilitated by already established connections between some fisheries biologists in British Columbia and the American scientists who were part of the Stanford ichthyological group and associated with previous Albatross voyages.
For instance, Californian John Pease Babcock was a fisheries advisor to the Government of British Columbia (1901-1909 and 1912-1933; Evenden, 2003)) and a colleague of Rutter (Jennings, 2014). It is likely Babcock was aware of the Albatross work that had been conducted during her stops in B.C. before the 1903 trip.

The 1903 voyage "experience" was therefore an additional example of the historical or cultural legacy the ship and her staff left in the region, notably in terms of the personal contacts made by scientists on the Albatross with Vancouver Island based biologists. Examples are the Reverend Taylor who figured significantly in development of scientific capacity of British Columbia marine biologists, specifically the establishment of the Pacific Biological Station in 1908 (Taylor, 1907; Rigby and Huntsman, 1938), and John Fannin from the B.C. Provincial Museum (BCPM, 1898).

Contacts between Taylor and scientists such as Gilbert, who was part of the Stanford University ichthyological group that included Jordan and Evermann, led to further cross border work after the cruise. For example, Taylor sent Gilbert an unidentified species of cottid from Departure Bay, which was subsequently described by Gilbert as a new species and named for Taylor (Gilbert, 1912). Additionally, the cruise had a relatively high profile in local newspapers whose reports raised public awareness of fisheries and marine ecology topics.

Contacts at these various levels of communication were a subtle but important part of the historical process or context that helped to build the critical mass of marine biology and ecology scientific expertise that we now see in British Columbia. As well, the increasing contacts at the scientific level between U.S. and Canadian fisheries biologists helped establish key international commissions such as the former International Pacific Salmon Commission and the International Pacific Halibut Commission which improved management of fisheries resources for the two countries. 


\section{Acknowledgments}

Thanks are owing to Gordon Miller and Rick Harbo for advice on finding early journal and newspaper records of Albatross in B.C. waters. Skip McKinnell and Eric Mills provided very good suggestions on earlier drafts of the paper. Archivists at California Academy of Sciences, U.S. National Archives, and the Smithsonian Institution were helpful. Discussions with Russ Coen and Katherine Pearson at the University of Washington were appreciated. Comments of four anonymous reviewers were very useful and informative.

\section{Literature Cited}

Alexander, A. B. 1893. Investigations of the steamer Albatross. Inshore Investigations (abstract). In U.S. Comm. Fish Fish., pt. XX, p. 229. Rep. Comm. for the year ending June 30, 1894. Publ. in 1896.

Bartsch, P. 1917. Descriptions of new west American mollusks and notes on previously described forms. Proc. U.S. Natl. Mus. 52(2193):636-681.

BCPM. 1898. A preliminary catalogue of the collections of natural history and ethnology in the Provincial Museum, Victoria, British Columbia. B.C. Columbia Provincial Mus.),Victoria, $200 \mathrm{p}$.

Dunn, J. R. 1997. Charles Henry Gilbert (18591928) pioneer ichthyologist of the American West. In T. W. Pietsch and W. D. Anderson (Editors), Collection building in ichthyology and herpetology. Am. Soc. Ichthyol. Herpetol., Spec. Publ. 3, p. 265-278.

Evenden, M. 2003. John Pease Babcock. In Dictionary of Canadian biography, vol. 16, Univ. Toronto/Université Laval (avail. at http:// www.biographi.ca/en/bio/babcock_john_ pease_16E.html, accessed 26 Sept. 2020).

Evening Star. 1903. Commissioner Bowers Returns. 30 June 1903, p. 11, Wash., D.C.

Evermann, B. W. 1903. Alaska salmon investigation, expedition. June 5 to September 25 1903. Calif. Acad. Sci. Archiv., Evermann (Barton Warren) papers, Collect. no. MSS.156 (Notes from June 1 to July 61903 , retrieved).

and E. L. Goldsborough. 1907.
The fishes of Alaska. Bull. U.S. Bur. Fish. 26:219-360.

Fassett, H. C. 1905. Records of the dredging and other collecting and hydrographic stations of the Fisheries Steamer Albatross in 1903. In U.S. Comm. Fish Fish., pt. XXIX, p. 123167. Rep. Comm. for the year ending 30 June 1903. Wash., D.C.

Fisheries and Oceans Canada. 2020. Inventory of water properties profiles. (avail. at https:// www.pac.dfo-mpo.gc.ca/science/oceans/data-donnees/search-recherche/profiles-eng.asp (accessed 18 Sept. 2020)

Gilbert, C. H. 1896, The ichthyological collections of the steamer Albatross during the years 1890 and 1891. Rep. U.S. Commiss. Fish Fish. 21:393-476.

1912. A new genus and species of cottoid fish from Departure Bay, Vancouver Island. Contrib. Can. Biol. Fish. 19061910:215-216.

Hedgpeth, J. W. (and W. L. Schmitt). 1945. The United States Fish Commission Steamer Albatross. The Am. Neptune 5:1-25.

Jennings, M. R. 1997. Barton Warren Evermann (1853-1932) and his contribution to North American ichthyology. In T. W. Pietsch and W. D. Anderson (Editors), Collection building in ichthyology and herpetology. Am. Soc. Ichthyol. Herpetol., Spec. Publ. 3, p. 291310 .

2014. Cloudsley Louis Rutter (1867-1903): Pioneer salmon biologist and resident naturalist, fisheries steamer Albatross. Mar. Fish. Rev. 76(4):1-26 (doi: https:// doi.org/10.7755/MFR.76.4.1).

Johnstone, K. 1977. The aquatic explorers. A history of the Fisheries Research Board of Canada. Univ. Toronto Press, Toronto, p. 342.

Jordan, D. S. 1896. Notes on fishes, little known or new to science. Proc. Calif. Acad. Sci. 2(6):201-244

and B. W. Evermann. 1904. Preliminary report of the Alaska Salmon Commission. United States 58th Congress, Second Sess., House of Rep. Doc. 477, 37 p.

McDorman, T. L. 2009. Salt water neighbours: International Ocean Law relations between the United States and Canada. Oxford Univ. Press, N.Y., 415 p.

Moore, J. P. 1908. Some Polychaetous annelids from the northern Pacific coast of North America. Proc. Acad. Nat. Sci. Phil. 60:321364.

Pawson, D. L., and D. J. Pawson, 2018. Diary of an ardent naturalist: letters from Austin $\mathrm{H}$. Clark to his wife from the 1906 cruise of the steamer Albatross. Mar. Fish. Rev. 80(4):182 (doi: https://doi.org/10.7755/MFR.80.4.1).
Pietsch, T. W., and J. W. Orr. 2019. Fishes of the Salish Sea. Heritage House and Univ. Wash. Press, Vancouver and Seattle, p. 942.

Rathbun, M. J. 1918. The Grapsoid crabs of America. U.S. Natl. Mus. Bull. 97, 390 p.

Richardson, H. 1905. Isopods from the Alaska salmon investigation. Bull. U.S. Bur. Fish. 24:209-221.

Rigby, M. S., and A. G. Huntsman, 1938. Materials relating to the history of the Fisheries Board of Canada (formerly the Biological Board of Canada) for the period 18981924. Fish. Res. Board Can., Manuscr. Rep. Ser. 660,282 p.

Roppel, P. 2004. The steamer Albatross and early Pacific salmon, Oncorhynchus spp., research in Alaska. Mar. Fish. Rev. 66(3):2131

Scagel, R. F. 1958. Indian Arm cruises, 1957; Queen Charlotte Strait cruises, 1957. Data Rep. 12, 35 p. Univ. B.C., Inst. Oceanogr., Vancouver.

Shor, E. N. 2020. David Starr Jordan (avail. at https://www.encyclopedia.com/people/science-and-technology/zoology-biographies/david-starr-jordan (accessed 16 Sept. 2020)).

Tanner, Z. L. 1889. Report upon the investigations of the US Fish Commission steamer Albatross for the year ending June 301889. U.S. Comm. Fish Fish. Rep. Comm. for 1888 , July 11888 to June 30 1889, pt. XVI, p. 395512

Taylor, G. W. 1907. A plea for a biological station on the Pacific Coast. Proc. Trans. R. Soc. Canada, Meeting of May 1907. Sect. IV, XIII:203-207.

The Daily Colonist. 1903. Professor Jordan Unsuccessful. Daily Colonist XC (10): p. 1, June 21, 1903. Victoria, B.C.

Townsend, C. H., 1901. Dredging and other records of the United States Fish Commission Steamer Albatross; with bibliography relative to the work of the vessel (extr. from U.S. Fish. Comm. Rep. for 1900, p. 387-562). U.S. Gov. Print. Off., Wash., D.C.

U.S. Bureau of Fisheries. 1920. Report of the United States Commissioner of Fisheries for the fiscal year 1920 with appendixes. Dredging and hydrographic records of the U.S Fisheries Steamer "Albatross" 1911-1920. Appendix III, 190 p. (Doc. No. 897, Issued Mar. 10, 1921)

Washington (D.C.) Times. 1903. Alaskan fisheries to be investigated. Wash. (D.C.) Times. April 22, 1903, p. 3. Wash., D.C.

Wilby, G. V. 1934. Ichthyological treasures from the "Albatross" expeditions in Canadian waters. Can. Field Nat. 48(8):121-126. 